\title{
Expressed sequence tags from larval gut of the European corn borer (Ostrinia nubilalis): Exploring candidate genes potentially involved in Bacillus thuringiensis toxicity and resistance
}

\author{
Chitvan Khajuria', Yu Cheng Zhu², Ming-Shun Chen ${ }^{1,3}$, \\ Lawrent L Buschman ${ }^{1}$, Randall A Higgins ${ }^{1}$, Jianxiu Yao ${ }^{1}$, Andre LB Crespo ${ }^{4}$, \\ Blair D Siegfried ${ }^{4}$, Subbaratnam Muthukrishnan ${ }^{5}$ and Kun Yan Zhu*1
}

\begin{abstract}
Address: ${ }^{1}$ Department of Entomology, 123 Waters Hall, Kansas State University, Manhattan, KS 66506, USA, ${ }^{2}$ Southern Insect Management Unit, USDA-ARS, 141 Experiment Station Road, Stoneville, MS 38776, USA, 3 Plant Science and Entomology Research Unit, USDA-ARS, Manhattan, KS 66506, USA, ${ }^{4}$ Department of Entomology, 202 Plant Industry Building, University of Nebraska, Lincoln, NE 68583, USA and ${ }^{5}$ Department of Biochemistry, 141 Chalmers Hall, Kansas State University, Manhattan, KS 66506, USA

Email: Chitvan Khajuria - chitvan@ksu.edu; Yu Cheng Zhu - yc.zhu@ars.usda.gov; Ming-Shun Chen - mchen@ksu.edu; Lawrent L Buschman - lbuschma@ksu.edu; Randall A Higgins - rhiggins@ksu.edu; Jianxiu Yao - jianxiuy@ksu.edu; Andre LB Crespo - andre.crespo@syngenta.com; Blair D Siegfried - bsiegfried1@unl.edu; Subbaratnam Muthukrishnan - smk@ksu.edu; Kun Yan Zhu* - kzhu@ksu.edu

* Corresponding author
\end{abstract}

Published: 29 June 2009

BMC Genomics 2009, 10:286 doi:10.1186/147|-2164-10-286
Received: 27 February 2009

Accepted: 29 June 2009

This article is available from: http://www.biomedcentral.com//47I-2/64/10/286

(c) 2009 Khajuria et al; licensee BioMed Central Ltd.

This is an Open Access article distributed under the terms of the Creative Commons Attribution License (http://creativecommons.org/licenses/by/2.0), which permits unrestricted use, distribution, and reproduction in any medium, provided the original work is properly cited.

\begin{abstract}
Background: Lepidoptera represents more than 160,000 insect species which include some of the most devastating pests of crops, forests, and stored products. However, the genomic information on lepidopteran insects is very limited. Only a few studies have focused on developing expressed sequence tag (EST) libraries from the guts of lepidopteran larvae. Knowledge of the genes that are expressed in the insect gut are crucial for understanding basic physiology of food digestion, their interactions with Bacillus thuringiensis $(\mathrm{Bt})$ toxins, and for discovering new targets for novel toxins for use in pest management. This study analyzed the ESTs generated from the larval gut of the European corn borer (ECB, Ostrinia nubilalis), one of the most destructive pests of corn in North America and the western world. Our goals were to establish an ECB larval gut-specific EST database as a genomic resource for future research and to explore candidate genes potentially involved in insect-Bt interactions and $\mathrm{Bt}$ resistance in ECB.

Results: We constructed two cDNA libraries from the guts of the fifth-instar larvae of ECB and sequenced a total of 15,000 ESTs from these libraries. A total of I2,5 I9 ESTs (83.4\%) appeared to be high quality with an average length of $656 \mathrm{bp}$. These ESTs represented 2,895 unique sequences, including I,738 singletons and I, I 57 contigs. Among the unique sequences, $62.7 \%$ encoded putative proteins that shared significant sequence similarities $\left(E\right.$-value $\left.\leq 10^{-3}\right)$ with the sequences available in GenBank. Our EST analysis revealed 52 candidate genes that potentially have roles in Bt toxicity and resistance. These genes encode 18 trypsin-like proteases, 18 chymotrypsin-like proteases, 13 aminopeptidases, 2 alkaline phosphatases and I cadherin-like protein. Comparisons of expression profiles of $4 \mid$ selected candidate genes between CrylAb-susceptible and resistant strains of ECB by RT-PCR showed apparently decreased expressions in 2 trypsin-like and 2 chymotrypsin-like protease genes, and I aminopeptidase genes in the resistant strain as compared with the
\end{abstract}


susceptible strain. In contrast, the expression of 3 trypsin- like and 3 chymotrypsin-like protease genes, 2 aminopeptidase genes, and 2 alkaline phosphatase genes were increased in the resistant strain. Such differential expressions of the candidate genes may suggest their involvement in CrylAb resistance. Indeed, certain trypsin-like and chymotrypsin-like proteases have previously been found to activate or degrade Bt protoxins and toxins, whereas several aminopeptidases, cadherin-like proteins and alkaline phosphatases have been demonstrated to serve as $\mathrm{Bt}$ receptor proteins in other insect species.

Conclusion: We developed a relatively large EST database consisting of 12,519 high-quality sequences from a total of 15,000 cDNAs from the larval gut of ECB. To our knowledge, this database represents the largest gut-specific EST database from a lepidopteran pest. Our work provides a foundation for future research to develop an ECB gut-specific DNA microarray which can be used to analyze the global changes of gene expression in response to $\mathrm{Bt}$ protoxins/toxins and the genetic difference(s) between Bt- resistant and susceptible strains. Furthermore, we identified 52 candidate genes that may potentially be involved in Bt toxicity and resistance. Differential expressions of 15 out of the $4 \mathrm{I}$ selected candidate genes examined by RT-PCR, including 5 genes with apparently decreased expression and 10 with increased expression in CrylAb-resistant strain, may help us conclusively identify the candidate genes involved in $\mathrm{Bt}$ resistance and provide us with new insights into the mechanism of Cryl Ab resistance in ECB.

\section{Background}

The genomic information on insects has increased tremendously during last several years. Whole genomes have been sequenced for several insect species, including the fruit fly (Drosophila melanogaster) [1], African malaria mosquito (Anopheles gambiae) [2], yellow fever mosquito (Aedes aegypti) [3], honey bee (Apis mellifera) [4], silkworm (Bombyx mori) [5,6], red flour beetle (Tribolium castaneum) [7], and 11 other Drosophila species [8,9]. Genome sequencing of other insect species, including pea aphid (Acyrthosiphon pisum), northern house mosquito (Culex pipiens), three species of parasitoid wasp (Nasonia sp.), Hessian fly (Mayetiola destructor), blood sucking bug (Rhodnius prolixus), and body louse (Pediculus humanus), are currently in progress [10-12]. The red flour beetle is the only agricultural insect pest whose whole genome sequence has become available to date.

Lepidoptera, the second most biodiverse group of insect species after Coleoptera, represents more than 160,000 species including many of the most devastating pests of crops, forests and stored products [13]. The silkworm was the first lepidopteran insect to have its complete genome sequenced [6]. However, genomic information for other lepidopterans, particularly agricultural pest species is limited but urgently needed due to their economic importance and biodiversity. Sequencing of the expressed sequence tags (ESTs) has been recognized as an economical approach to identify a large number of expressed genes that can be used in gene expression and other genomic studies [14-16]. Indeed, ESTs have been generated from several lepidopteran insects including the silkworm [17], spruce budworm (Choristoneura fumiferana) [18], cotton bollworm (Helicoverpa armigera) [19], diamondback moth (Plutella xylostella) [20], tobacco hawkmoth (Manduca sexta) $[21,22]$, and fall armyworm (Spodoptera frugiperda) $[10,23]$.

It has been long recognized that the insect gut is an important target for developing new strategies for insect pest management. Until now, however, only a few studies have focused on the development of gut-specific EST libraries of lepidopterans as a tool to identify candidate genes involved in the toxicity of insecticides and the development of insecticide resistance. Gut-specific EST libraries were reported for light brown apple moth (Epiphyas postvittana) $(6,416$ ESTs $)$ [24], bertha armyworm (Mamestra configurata) (30 serine protease-related sequences) [25], and European corn borer (ECB, Ostrinia nubilalis) (1,745 ESTs) [26].

ECB is one of the most destructive pests of corn and can cause as much as $\$ 1$ billion of economic loss annually in the United States alone $[27,28]$. ECB also represents a complex of stalk borers, such as the southwestern corn borer (Diatraea grandiosella) and the sugarcane borer (Diatraea saccharalis). These stalk borers share similar ecosystem and create similar damage to corn plants. Although ECB has been successfully managed using transgenic Bt corn hybrids (plants that express insecticidal toxins of Bacillus thuringiensis or $\mathrm{Bt}$ ), there are increasing concerns about the potential development of Bt resistance in ECB because of the widespread use of Bt corn $[28,29]$. Indeed, several ECB colonies have developed resistance to Bt toxins under laboratory selection conditions [30,31].

The main target for Bt toxins is the insect midgut, where $\mathrm{Bt}$ protoxins are activated by gut proteases to produce acti- 
vated Bt toxins. The activated toxins then bind to specific receptor(s) to confer toxicity [32]. This means that insect resistance to Bt toxins could be conferred by proteasemediated and receptor-mediated mechanisms [33-37]. Because Bt toxins and insect gut interactions are determined by many gene products in the insect gut, including many proteins/enzymes involved in Bt protoxin activation, toxin binding to receptors and toxin degradation, any change in these systems has the potential to affect a particular Bt's specificity and efficacy, and could lead to Bt resistance in insects.

Our goals are to develop a gut-specific EST database from ECB larvae and explore candidate genes that are potentially involved in insect-Bt interactions and Bt resistance. In this paper, we report the analysis and annotations of 15,000 ESTs derived from the gut of ECB larvae. We discuss the putative identities of the ESTs, their potential biological and molecular functions, and present comparative analyses of our ESTs with sequences from other insects. This work provides the opportunity for developing an ECB gut-specific microarray that can be used to study insect-Bt interactions and genetic basis of Bt resistance in ECB. Furthermore, we revealed 52 candidate genes that could be involved in $\mathrm{Bt}$ toxicity and resistance. Among the 41 selected candidate genes examined by RT-PCR, we found 5 genes with apparently decreased expressions and 10 with increased expressions in Cry1Ab-resistant strain of ECB as compared with the susceptible strain of ECB. Differential expressions of these genes in a Cry1Ab-resistant strain may suggest possible involvement of these genes in Cry $1 \mathrm{Ab}$ resistance, and therefore provides us with new insights into the mechanism of Cry $1 \mathrm{Ab}$ resistance in ECB. This study may serve as a model for studying Bt resistance mechanisms and for developing bio-pesticides for all closely related corn stalk borers.

\section{Results and discussion}

\section{Development and analysis of the ECB gut ESTs}

We first used PPCR-XL-TOPO plasmid vector to prepare a cDNA library using total RNA purified from the whole guts of fifth-instar larvae of ECB. After we sequenced a total of 1,152 cDNA clones, we found that the cDNA inserts in the vector were not sufficient long (average length: $441 \mathrm{bp}$ ). Therefore, we used lambda Uni-ZAP RX vector to prepare a second cDNA library using mRNA purified from the guts of fifth-instar larvae of ECB. This library provided us with much longer cDNA inserts (average length: $674 \mathrm{bp}$ ). Because of this significantly improved quality of the ESTs generated from the lambda library, we used the lambda library for our further sequencing of ESTs. Among the 15,000 random cDNA clones sequenced, only $<8 \%$ were from the plasmid library whereas $>92 \%$ were from the lambda library (Table 1).

Our analysis of the 15,000 sequences resulted in 13,066 readable sequences (i.e., $87.1 \%$ success rate). These sequences were first trimmed for removal of vector sequences and then were subjected to filtration to exclude the sequences of $<100 \mathrm{bp}$. Further analysis, using RepeatMasker and Organelle Masker programs [38], removed an additional 547 sequences. Thus, the total number of high quality sequences obtained was 12,519 (83.4\%) with an average length of $656 \mathrm{bp}$ (Table 1). These high quality sequences have been deposited in the EST database (dbEST) with GenBank accession numbers from GH987145 to GH999663 at the National Center for Biotechnology Information (NCBI). Redundancy and assembly analyses of the high quality sequences using Sequencher software (Gene Codes Corp., Ann Arbor, MI, USA) resulted in 2,895 unique ESTs, including 1,157 contiguous sequences (contigs) that consist of 2 or more sequences, and 1,738 singletons that represent single sequences. The majority of the contigs were assembled from 10 or fewer ESTs (Figure 1A). On average, however, each contig was assembled from 10.1 sequences due to a few highly redundant ESTs. Putative identities of the unique sequences were determined by searching the nonredundant database in GenBank using BLASTx. Among the 2,895 unique sequences, $1,816(62.7 \%)$ showed significant matches at $E$-values of $\leq 10^{-3}$, whereas the remain-

Table I: Summary of the analysis of 15,000 ESTs from the guts of the European corn borer larvae

\begin{tabular}{|c|c|c|c|c|c|c|c|c|c|}
\hline \multirow[t]{2}{*}{ Library } & \multirow[t]{2}{*}{$\begin{array}{l}\text { Sequence } \\
\text { direction }\end{array}$} & \multirow{2}{*}{$\begin{array}{r}\text { Number of } \\
\text { clones } \\
\text { sequenced }\end{array}$} & \multicolumn{2}{|c|}{$\begin{array}{l}\text { Chromatographs checked } \\
\text { (EST number) }\end{array}$} & \multicolumn{2}{|c|}{$\begin{array}{l}\text { Sequence quality checked } \\
\text { (EST number) }\end{array}$} & \multirow[t]{2}{*}{$\begin{array}{l}\text { Average } \\
\text { length (bp) }\end{array}$} & \multirow[t]{2}{*}{$\begin{array}{l}\text { Number of } \\
\text { contigs } b\end{array}$} & \multirow[t]{2}{*}{$\begin{array}{l}\text { Number of } \\
\text { singletons }\end{array}$} \\
\hline & & & Good quality & Poor quality ${ }^{a}$ & Good quality & Poor quality & & & \\
\hline Plasmid & 3'-end & 1,152 & 764 & 388 & 722 & 42 & 441 & & \\
\hline Uni-ZAP RX & 5 '-end & 13,848 & 12,302 & 1,546 & II,797 & 505 & 674 & & \\
\hline Total & -- & 15,000 & 13,066 & 1,934 & 12,519 & 547 & 656 & 1,157 & 1,738 \\
\hline
\end{tabular}

$a$ The poor quality sequences were discarded and were not included in the analysis.

${ }^{b}$ The numbers of contigs and singletons were based on the analysis of all the ESTs sequenced from the two libraries. 
A

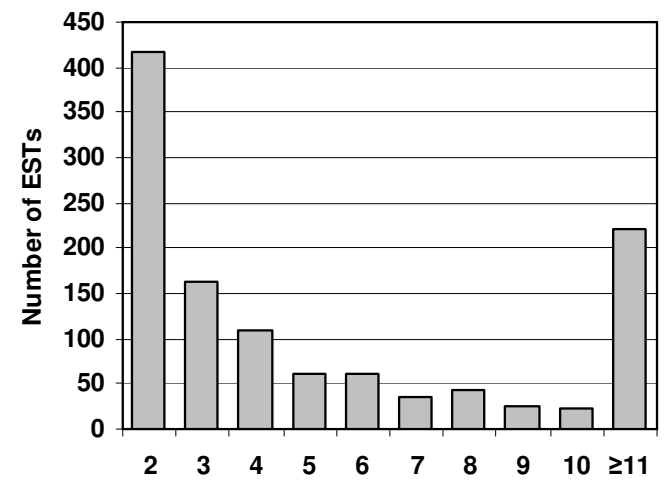

B

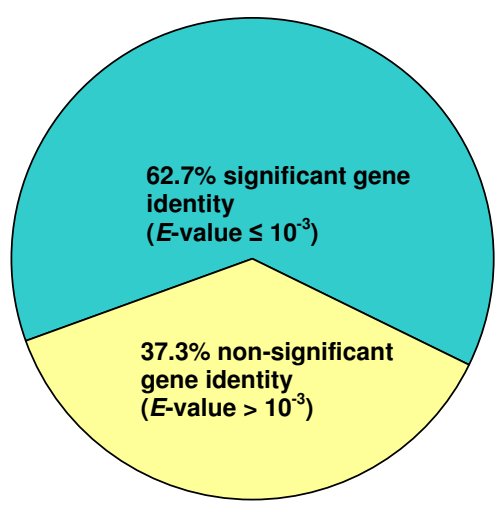

Figure I

(A) Distribution of ECB gut-specific ESTs in each contig. (B) Distribution of the 2,895 ECB gut-specific contigs and singletons with or without match in NCBI database using BLASTx. Sequences were defined as identical or similar CDNA sequences when they had $E$-values $\leq 10^{-3}$.

ing 1,077 (37.3\%) did not exhibit meaningful matches (Figure 1B).

\section{Transcript abundance}

The abundance of transcripts for a particular gene of an organism can be estimated from the corresponding EST abundance in a cDNA library [39]. The most abundant ESTs in our CDNA libraries were those encoding trypsinlike proteases and chymotrypsin-like proteases (Table 2). As this CDNA library was constructed from the gut of ECB, the high number of transcripts from the digestive enzymes was expected. The most abundant contig was \#0038 which consisted of 525 ESTs, and it included $4 \%$ of the total sequences. This contig shared maximum sequence similarity with the trypsin-like protease, T25 precursor, characterized previously in ECB [40]. Other abundant transcripts were contigs \#0026 and \#0062. Contig \#0026 included 197 ESTs and encoded a putative chymotrypsinlike protease. Contig \#0062 included 137 ESTs and encoded a putative trypsin-like serine protease. The highly expressed genes in ECB larval gut may have important implications for their growth and development. However,

Table 2: List of 20 largest contigs assembled from 15,000 ESTs from the guts of European corn borer larvae

\begin{tabular}{|c|c|c|c|c|c|}
\hline Contig Identification & Putative identities & Number of ESTs & Length (bp) & $\%$ Total & $E$-value \\
\hline Contig [0038] & Trypsin-like protease T25 precursor & 525 & 942 & 4.1 & $3 e-148$ \\
\hline Contig [0026] & Chymotrypsin-like serine protease & 197 & 1,321 & 1.5 & le-149 \\
\hline Contig [0062] & Trypsin-like serine protease & 132 & 1,076 & 1.0 & $|e-| 3 \mid$ \\
\hline Contig [0074] & Unknown & $|3|$ & 824 & 1.04 & -- \\
\hline Contig [0059] & Trypsin-like serine protease & 129 & 1,497 & 1.0 & $1 \mathrm{e}-117$ \\
\hline Contig [0076] & Trypsin-like serine protease & 129 & 1,133 & 1.0 & $1 \mathrm{e}-148$ \\
\hline Contig [0077] & Unknown & 97 & 652 & 0.77 & -- \\
\hline Contig [0060] & Unknown & 94 & 1,218 & 0.75 & -- \\
\hline Contig [0I25] & Ribosomal protein s 13 & 87 & 888 & 0.69 & le-79 \\
\hline Contig [0092] & Trypsin-like serine protease & 80 & 1,238 & 0.63 & le-149 \\
\hline Contig [0102] & Unknown & 80 & 800 & 0.63 & -- \\
\hline Contig [0040] & Thymosin isoform I & 78 & $\mathrm{I}, 447$ & 0.62 & le-80 \\
\hline Contig [0243] & Trypsin-like serine protease & 78 & 701 & 0.62 & $1 \mathrm{e}-120$ \\
\hline Contig [0034] & Unkown & 76 & 567 & 0.60 & le-60 \\
\hline Contig [0124] & Pancreatic triacylglycerol lipase & 75 & 1,263 & 0.59 & le-99 \\
\hline Contig [0426] & Chymotrypsin-like serine protease & 73 & 1,439 & 0.58 & $1 \mathrm{e}-129$ \\
\hline Contig [0|46] & Unknown & 71 & 839 & 0.56 & -- \\
\hline Contig [0997] & Unknown & 71 & 574 & 0.56 & -- \\
\hline Contig [00I3] & Unknown & 68 & 1,244 & 0.54 & -- \\
\hline Contig [0175] & Phosphate mannosyltransferase & 65 & 1,121 & 0.51 & le-20 \\
\hline
\end{tabular}


care must be taken in making general conclusions about the redundancy of EST's because some artifacts could also be involved [41].

\section{Identification of the ORF and putative secretary proteins} The 2,895 contigs and singletons were subjected to the ORF predictor software to identify the open reading frame (ORF) of the sequences. This was done to identify the novel gene candidates, which have clear coding capacity. Among 2,895 unique ESTs, 1,119 (38.7\%) had ORFs of at least 450 bp. Among 1,119 ORFs, 994 putative protein sequences $(88.8 \%)$ shared sequence similarity (E-value $\leq$ $10^{-3}$ ) with known proteins in the non-redundant (NR) protein database in GenBank, whereas 125 (11.2\%) did not share significant similarity with any known protein in the same database (Figure 2A). Thus, at least $11.2 \%$ of the protein-coding genes in the gut of ECB are potentially new genes. The remaining 1,553 contigs and singletons (53.6\%) had an ORF of <450 bp and 223 (7.7\%) did not have an ORF. Among the ESTs with ORFs of <450 bp, 452 $(29.2 \%)$ had matches in the NR protein database, whereas $1,011(70.8 \%)$ did not have matches. Many sequences did not have ORF of $\geq 450$ bp because the sequences were too short (approximately 650 sequences were less than 450 bp). The lack of the ORFs in other sequences can be due to frame shift errors, 5' truncation of cDNA clones and the ESTs that were not derived from mRNA [42].

To identify the secretory proteins, putative protein sequences were examined to identify potential secretion signal peptide using SignalP software [43]. A total of 439 $(15.2 \%)$ putative proteins were predicted to contain signal peptides (Figure 2B). Among the putative secretory proteins, 298 sequences $(67.9 \%)$ had matches with known proteins in the NR protein database, whereas 141 putative secretory proteins $(32.1 \%)$ were unique, sharing no significant sequence similarity with any known protein. This information is valuable since secretory proteins

\section{A}

Sequences with more than 450 bp ORF region

\section{Sequences with less than} 450 bp ORF region

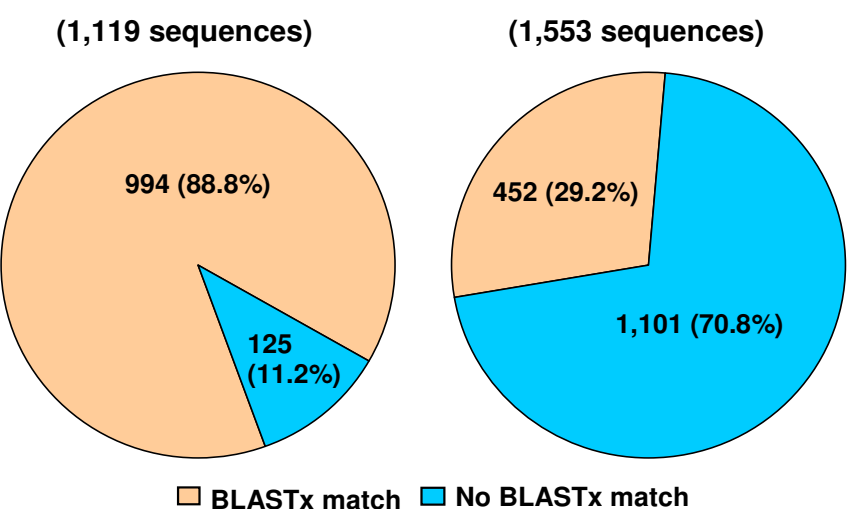

B

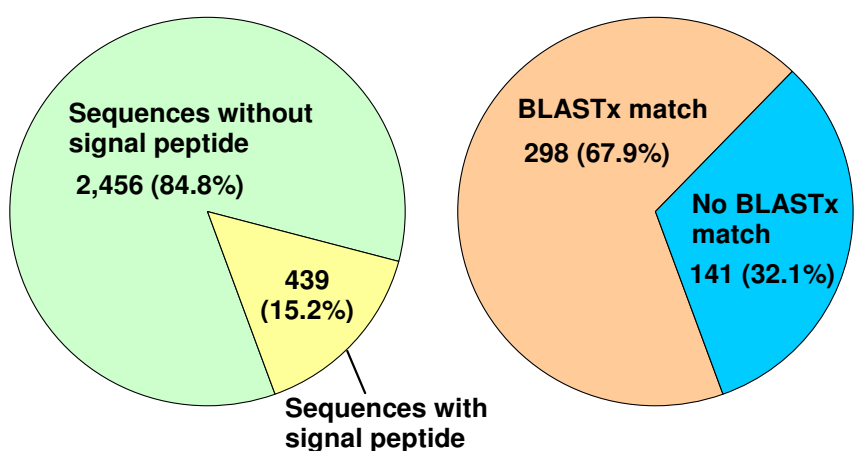

Figure 2

Open reading frame (ORF), secretory protein, and BLASTx results. (A) The proportion of the unique ESTs from ECB gut cDNA library with or without 450 bp of ORF region along with their matches in BLASTx using NCBI database. (B) Proportion of the unique ESTs with or without signal peptide along with their match in BLASTx using NCBI database. 
are important components of biological processes in the gut $[44,45]$.

\section{Comparative analyses of ECB gut ESTs}

The development of EST databases has been recognized as a rapid method of sampling an organism's transcriptome and is complementary to a whole genome-sequencing project [46]. Indeed, a large number of ESTs have been generated from other model organisms. The 2,895 contigs and singletons obtained from the larval gut of ECB were compared with the sequences from other organisms. The first hits (highest score) of the sequences in the NR database were taken into account to determine the most similar organism. The largest number of first hit sequences (390; 13.5\%) came up with B. mori (Figure 3). This can be explained by the fact that the genome of $B$. mori has been sequenced and partially annotated, and that both ECB and $B$. mori are lepidopterans. The second largest number of first hit sequences $(290 ; 10.0 \%)$ was with $T$. castaneum, followed by Ae. aegypti (109; 3.8\%), Culex pipiens (91; $3.1 \%)$, and A. gambiae $(81 ; 3.8 \%)$. Only $2.5 \%$ of the sequences (72) were found to be most similar to predicted protein sequences from $O$. nubilalis. This is simply due to the very small number of sequences currently available in NCBI database from ECB.

In order to compare our ECB gut ESTs with the 1,745 ECB ESTs that are already available in NCBI database, we per-

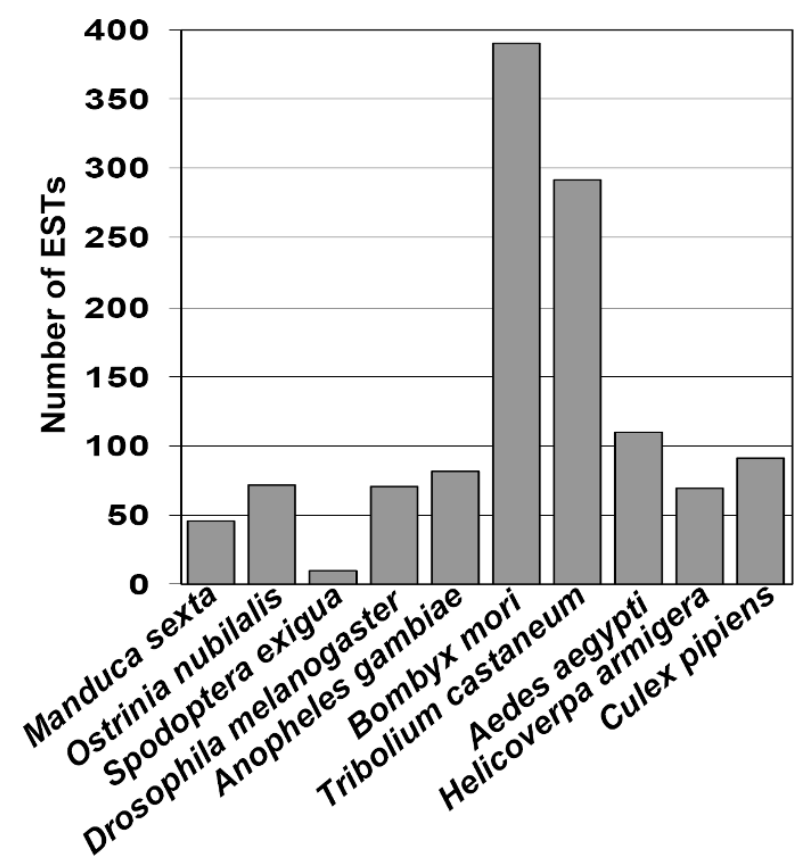

Figure 3

Similarity of ECB gut-specific ESTs with other insects. The first hit sequence (highest score) was used to determine the most similar organism. formed BLASTN searches. Among our 2,895 contigs and singletons, $1,279(44.2 \%)$ had significant matches at a cutoff $E$-value of $\leq 10^{-3}$ whereas $1,616(55.8 \%)$ did not show any significant matches in NCBI database using BLASTN search. We compared our ECB ESTs with the ECB ESTs available in NCBI dbEST database. We found 475 sequences $(16.4 \%)$ that had significant matches with $E$ values less than $E-150$ (Figure 4A). Within this category, 88 ESTs $(3.0 \%)$ had matches with $E$-values less than $E$ 150, $23(0.8 \%)$ had $E$-values between $E-150$ and $E-100$, 131 (4.5\%) had $E$-values of $E-100$ and $E-50,152$ (5.2\%) had $E$-values of $E-50$ and $E$-20, and $81(2.7 \%)$ had $E$-values between $E-20$ and $E-5$ (Figure 4B). A total of 2,420 ESTs (83.6\%) had no hits with currently available midgut ESTs in NCBI database.

Because $B$. mori genome has not been fully annotated, we have also compared our ESTs with all available B. mori ESTs using BLASTN. Among the 2,895 contigs and singletons, $579(20.0 \%)$ had hits with $B$. mori sequences at $E$ value $<10^{-3}$ (Figure 4A). The remaining 2,316 ESTs $(80.0 \%)$ did not show a significant match with the B. mori sequences. Among the 579 unique ESTs which had hits in the database, $43(7.4 \%)$ had matches with $E$-value less than $E$-150, 64 (11.1\%) had $E$-values between $E$-150 and $E$-100, $156(26.9 \%)$ had $E$-values between $E-100$ and $E$ 50, $135(23.3 \%)$ had $E$-values between $E$-50 and $E-20$, and 181 sequences $(31.3 \%)$ had $E$-values between $E-20$ and $E-5$ (Figure $4 \mathrm{~B})$.

\section{Gene ontology}

Blast2GO software was used to obtain the gene ontology (GO) terms for the unique sequences by comparing them through the Gene Ontology Consortium [47]. Among the 2,895 contigs and singletons, 1,815 showed blast hits at $E$ value $\leq 10^{-3}$ and 1,119 ESTs of the 1,815 were mapped. A total of 120 mapped ESTs showed both the GO terms and Enzyme Commission (EC) numbers. Figure 5 shows the EST functional categories, where the ECB unique ESTs were assigned to putative biological processes, molecular functions, and cellular components. Within the biological process category, $24.0 \%$ belong to cellular processes, followed by $17.0 \%$ metabolic processes, $11.0 \%$ developmental processes, $11.0 \%$ multi-cellular processes, and $8.0 \%$ each for biological regulation and localization. In the molecular function category, the maximum GO terms $(40.0 \%)$ are included in catalytic activity, followed by binding $(31.0 \%)$, transporter activity $(10.0 \%)$, and $5.0 \%$ each for enzyme regulation activity and structural molecular activity $(9.0 \%)$. In cellular components category, cell part, cell, and organelle had $27.0 \%, 24.0 \%$, and $18.0 \%$ of the GO terms, respectively. They were followed by organelle part $(13.0 \%)$, macromolecular complex $(11.0 \%)$, envelope $(4.0 \%)$, and membrane-enclosed lumen $(3.0 \%)$. 
A

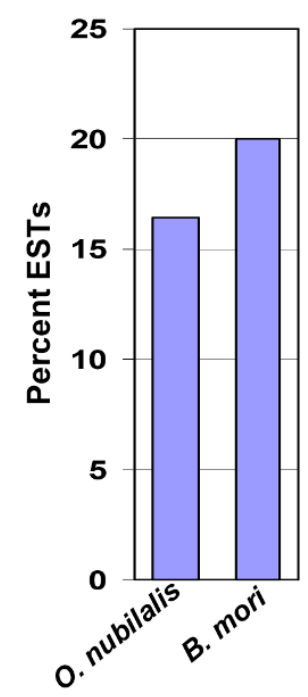

B

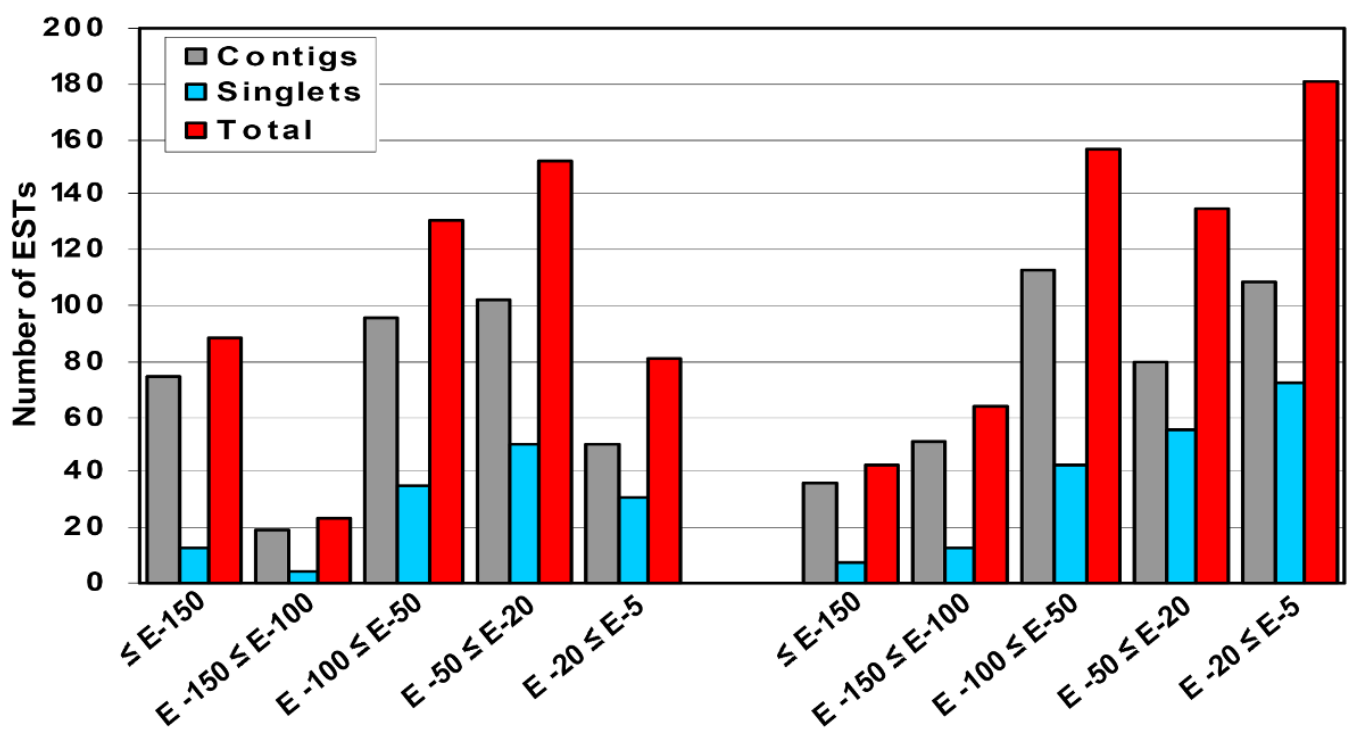

Ostrinia nubilalis

Bombyx mori

\section{Figure 4}

(A) Percentage of the 2,895 ECB gut-specific unique ESTs which shared matches with O. nubilalis and B. mori sequences with E-value ranging from E-I 50 to E-5 using BLASTN. (B) Comparative analyses of the 2,895 ECB gut-specific unique ESTs to $B$. mori sequences and other $O$. nubilalis sequences available in NCBI database using BLASTN.

\section{Identification of ESTs potentially relevant to the Bt toxicity and resistance}

The mode of Bt action in insects includes the ingestion of Bt protoxins, solubilization of Bt protoxins in insect gut, proteolytic activation of protoxins, binding of toxins to $\mathrm{Bt}$ receptors, membrane integration, pore formation, cell lysis, and insect death [48]. According to this mode of action, a target insect could potentially develop resistance to $\mathrm{Bt}$ protoxins or toxins via one or more changes in the Bt-receptor interaction pathway. Indeed, the two most commonly identified Bt resistance mechanisms are protease-mediated and receptor-mediated resistance [49]. Our analysis of ESTs derived from the larval gut of ECB revealed a number of genes that are potentially involved in Bt toxicity and resistance (Table 3). Specifically, we identified 18 ESTs putatively encoding trypsin-like proteases and 18 ESTs putatively encoding chymotrypsin-like proteases with $E$-value ranges from $2 e-26$ to $3 e-137$ and $E$ value $3 e-27$ to $3 e-149$, respectively. Changes in the proteolytic activity of digestive enzymes can alter the toxicity of Bt protoxins or toxins through effects on crystal solubilization and/or activation of protoxins, as well as degradation of activated toxin [33,50-56]. A previous study from our lab has shown that Bt resistance in a Dipel-resistant strain of ECB was primarily associated with reduced trypsin-like protease activity [35,40]. These trypsin-like proteases were also revealed in our EST analysis. Thus, our analysis of the ESTs generated from the guts of ECB larvae revealed many more candidate genes that deserve further analysis for their roles in Bt toxicity and resistance in ECB.

Our EST analysis also revealed 13 ESTs putatively encoding aminopeptidases (E-value $1 \mathrm{e}-64$ to $1 \mathrm{e}-116), 1$ encoding a cadherin-like protein (E-value $1 \mathrm{e}-35)$, and 2 encoding alkaline phosphatases (E-value $1 \mathrm{e}-115$ to $1 \mathrm{e}$ 131). Aminopeptidase $N$, cadherin-like proteins, and alkaline phosphatases have been found to serve as $\mathrm{Bt}$ toxin binding receptors in other insect species [57-59]. To verify the function of aminopeptidase $\mathrm{N}$ as a receptor for Bt Cry1Ac toxin in Spodoptera litura, RNAi technology was used to reduce the expression of aminopeptidase N. This resulted in a significant reduction in the susceptibility of the insect to Cry1Ac toxin [60]. Gahan et al. [61] showed that in a resistant strain (YHD2) of Heliothis virescens, there was a disruption of a cadherin-superfamily gene by a retrotransposon-mediated insertion that resulted in high levels of resistance to the Bt toxin Cry1Ac. Fernandez et al. [62] also reported that a GPI (glycosylphosphatidyl- 


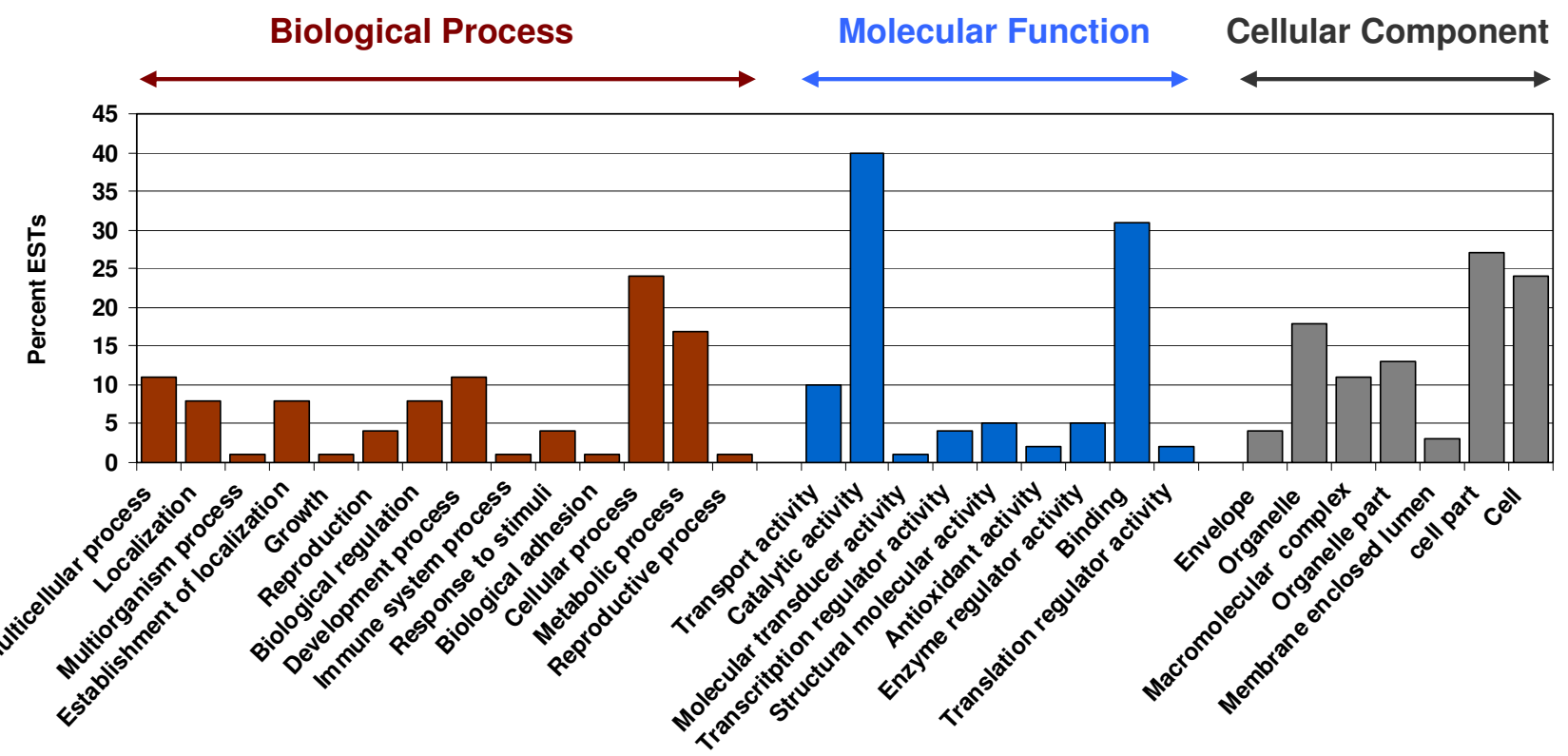

\section{Figure 5}

Distribution of the ECB gut-specific unique ESTs annotated at GO level 2. The Y-axis shows the percentage of the sequences. The $\mathrm{X}$-axis shows 3 areas of annotation and with each area the sequences were further divided into subgroups at GO level 2.

inositol)-anchored ALP (alkaline phosphatase) was an important receptor molecule involved in Cry11Aa interactions with midgut cells and toxicity to Ae. aegypti larvae. These studies demonstrate that aminopeptidases, cadherin-like proteins, and alkaline phosphatases can serve as $\mathrm{Bt}$ toxin receptors involved in Bt toxicity and resistance. Thus, identification of these candidate $\mathrm{Bt}$ receptor genes in this study will allow us to further examine whether receptor-mediated resistance is involved in Bt resistance in ECB.

\section{Comparison of expression profiles between CrylAb- susceptible and resistant strains of ECB}

We performed RT-PCR to compare the expression patterns of the candidate genes relevant to Bt toxicity and resistance between Cry1 Ab-susceptible and resistant strains of ECB. Among 41 selected genes from the 52 candidate genes, which included 15 that putatively code for trypsinlike serine proteases, 13 for chymotrypsin-like serine proteases, 10 for aminopeptidases, 2 for alkaline phosphatases, and 1 for cadherin-like protein, we found apparently decreased expressions in 2 trypsin-like and 2 chymotrypsin-like protease genes, and 1 aminopeptidase genes in the resistant strain as compared with the susceptible strain (Figure 6). Among these genes, 2 trypsin-like protease genes (contig [0907] and ECB-30-C08) were virtually absent in the resistant strain. In contrast, we found apparently increased expressions in 3 trypsin-like and 3 chymotrypsin-like protease genes, 2 aminopeptidase genes, and 2 alkaline phosphatase genes in the resistant strain. The most noticeable increases were found in 1 trypsin-like protease (contig [3395]), 3 chymotrypsin-like protease (ECB-V-25_E02, contig [0379], and ECB23_F02), 1 alkaline phosphatase (contig [5091]), and 1 aminopeptidase (ECB-D12) genes.

Although RT-PCR is not quantitative, reproducible results of such differential expression patterns for these candidate genes in the Cry1Ab-susceptible and resistant strains of ECB may imply their potential roles in conferring or contributing to Cry $1 \mathrm{Ab}$ resistance as well as genetic differences between the susceptible and resistant strains of ECB. Indeed, certain trypsin-like and chymotrypsin-like proteases have previously been found to activate or degrade Bt protoxins and toxins, whereas several aminopeptidases, cadherin-like proteins and alkaline phosphatases have been demonstrated to serve as $\mathrm{Bt}$ receptor proteins in other insect species. Thus, our results may help conclusively identify the candidate genes involved in Cry $1 \mathrm{Ab}$ resistance and provide us with new insights into the mechanism of Cry $1 \mathrm{Ab}$ resistance in ECB. Nevertheless, further research will be needed to confirm their involvements and to elucidate their roles in Cry $1 \mathrm{Ab}$ resistance in ECB. 
Table 3: List of genes potentially involved in Bt toxicity and resistance as identified by EST analysis from the guts of the European corn borer larvae

\begin{tabular}{|c|c|c|c|c|c|c|c|c|}
\hline \multicolumn{7}{|c|}{ European corn borer } & \multicolumn{2}{|l|}{ Silkworm ${ }^{b}$} \\
\hline & EST ID & Matches & Organism $^{a}$ & \% Identities & E-value & Matches & \% Identities & E-value \\
\hline \multicolumn{9}{|c|}{ Trypsin-like serine proteases } \\
\hline I & Contig [0038] & AAR989I8.I & Ostrinia nubilalis & $254 / 256(99 \%)$ & $3 e-148$ & AAB26023.I & $144 / 233(61 \%)$ & $2 e-78$ \\
\hline 2 & Contig [0157] & ACB54937.I & $\begin{array}{l}\text { Helicoverpa } \\
\text { armigera }\end{array}$ & $46 / 97(47 \%)$ & $8 e-18$ & No match & -- & -- \\
\hline 3 & Contig [0I II] & ABF47507.I & Ostrinia furnacalis & $248 / 257$ (96\%) & $5 e-135$ & AAB26023.I & $|36 / 23|(58 \%)$ & $2 e-64$ \\
\hline 4 & Contig [0291] & AAX62039.1 & Ostrinia nubilalis & $257 / 258$ (99\%) & $5 e-137$ & AAB26023.I & $100 / 240(41 \%)$ & le-43 \\
\hline 5 & Contig [0486] & ABU98624.I & $\begin{array}{l}\text { Helicoverpa } \\
\text { armigera }\end{array}$ & $|48 / 24|(6 \mid \%)$ & le-72 & AAB26023.I & $109 / 235(46 \%)$ & $4 e-48$ \\
\hline 6 & Contig [0754] & AAX62034.I & Ostrinia nubilalis & $154 / 266(57 \%)$ & $7 e-69$ & AAB26023.I & $128 / 244(52 \%)$ & $3 e-56$ \\
\hline 7 & Contig [0622] & ABU98624.I & $\begin{array}{l}\text { Helicoverpa } \\
\text { armigera }\end{array}$ & $145 / 249(58 \%)$ & $4 e-82$ & AAB26023.I & $101 / 238(42 \%)$ & $3 e-50$ \\
\hline 8 & Contig [0907] & ABU986।9.1 & $\begin{array}{l}\text { Helicoverpa } \\
\text { armigera }\end{array}$ & $89 / 206$ (43\%) & $6 e-47$ & No match & -- & -- \\
\hline 9 & Contig [1007] & AAR98918.I & Ostrinia nubilalis & $218 / 252(86 \%)$ & $1 \mathrm{e}-120$ & AAB26023.I & $119 / 229(51 \%)$ & le-57 \\
\hline 10 & Contig [1400] & ABU98619.1 & $\begin{array}{l}\text { Helicoverpa } \\
\text { armigera }\end{array}$ & $56 / 199$ (28\%) & $2 e-2 I$ & No match & -- & -- \\
\hline II & Contig [1615] & ABF47507.I & Ostrinia furnacalis & $101 / 189(53 \%)$ & le-64 & AAB26023.I & $95 / 183$ (51\%) & $5 e-50$ \\
\hline 12 & Contig [3395] & AAX62032.I & Ostrinia nubilalis & $129 / 209$ (61\%) & $3 e-72$ & AAB26023.I & $117 / 208(56 \%)$ & $7 e-59$ \\
\hline 13 & Contig [4300] & AAX62035.I & Ostrinia nubilalis & $79 / 84$ (94\%) & $8 e-43$ & AAB26023.I & $43 / 72(59 \%)$ & $5 e-16$ \\
\hline 14 & Contig [4291] & AAX62032.I & Ostrinia nubilalis & $181 / 236(76 \%)$ & $2 e-105$ & AAB26023.I & $138 / 233(59 \%)$ & $7 e-75$ \\
\hline 15 & ECB-30_C08 & AAX62036.I & Ostrinia nubilalis & $36 / 45(80 \%)$ & $1 \mathrm{e}-13$ & No match & -- & -- \\
\hline 16 & ECB-17_C09 & ABC8705I.I & Ostrinia furnacalis & $65 / 98(66 \%)$ & $5 e-30$ & AAB26023.I & 48/97 (49\%) & $4 e-19$ \\
\hline 17 & ECB-C-I8_BII & AAR98920.2 & Ostrinia nubilalis & $198 / 204(97 \%)$ & $5 e-114$ & No match & -- & -- \\
\hline 18 & ECB-V-26_H09 & ABC8705I.I & Ostrinia furnacalis & $35 / 50(70 \%)$ & $6 e-12$ & NP_00I040350 & $24 / 48$ (50\%) & $3 e-04$ \\
\hline \multicolumn{9}{|c|}{ Chymorypsin-like serine proteases } \\
\hline I & Contig [0026] & AAX62029.1 & Ostrinia nubilalis & $258 / 261$ (98\%) & $5 e-149$ & NP_001036903.I & $163 / 259(62 \%)$ & le-86 \\
\hline 2 & Contig [0058] & AAX62029.I & Ostrinia nubilalis & $228 / 261$ (87\%) & $3 e-120$ & No match & -- & -- \\
\hline 3 & Contig [0120] & AAF7I5I5.I & Agrotis ipsilon & $174 / 287(60 \%)$ & $2 e-84$ & NP_001040430.I & $109 / 244(44 \%)$ & $2 e-47$ \\
\hline 4 & Contig [014I] & AAX62028.1 & Ostrinia nubilalis & $197 / 262(75 \%)$ & $|e-| 0 \mid$ & NP_001040430.I & $|30 / 26|(49 \%)$ & $2 e-52$ \\
\hline 5 & Contig [0|87] & AAX62026.I & Ostrinia nubilalis & 193/202 (95\%) & $4 e-97$ & No match & -- & -- \\
\hline 6 & Contig [0299] & AAX62029.1 & Ostrinia nubilalis & $228 / 261$ (87\%) & $6 e-120$ & NP_001036903.I & $166 / 259(64 \%)$ & $7 e-82$ \\
\hline 7 & Contig [0379] & AAX62030.I & Ostrinia nubilalis & I I I/242 (45\%) & le-55 & NP_001036903.I & $109 / 236(46 \%)$ & $8 e-55$ \\
\hline 8 & Contig [0426] & AAX62026.I & Ostrinia nubilalis & $282 / 289(97 \%)$ & Ie-129 & No match & -- & -- \\
\hline 9 & Contig [0560] & NP_001040430.I & Ostrinia nubilalis & $128 / 232(55 \%)$ & le-63 & NP_001040430.I & $17 \mid / 272(62 \%)$ & $4 e-93$ \\
\hline 10 & Contig [0806] & AAX62029.1 & Ostrinia nubilalis & $202 / 208$ (97\%) & $6 e-137$ & No match & -- & -- \\
\hline II & Contig [106I] & CAL92020.I & Manduca sexta & $169 / 281$ (60\%) & le-87 & No match & -- & -- \\
\hline 12 & Contig [1478] & NP_001040430.I & Bombyx mori & $152 / 260(58 \%)$ & $5 e-84$ & NP_001040430.I & $152 / 260(58 \%)$ & $4 e-84$ \\
\hline 13 & Contig [2079] & AAL93243.I & Aedes aegypti & $85 / 242(35 \%)$ & $7 e-40$ & No match & - & -- \\
\hline 14 & Contig [2569] & AAF7I5I8.I & Helicoverpa zea & $119 / 240(49 \%)$ & $7 e-49$ & NP_001040430.I & $87 / 212$ (4I\%) & le-30 \\
\hline 15 & Contig [4479] & AAC 36150.1 & $\begin{array}{l}\text { Plodia } \\
\text { interpunctella }\end{array}$ & $140 / 263(53 \%)$ & $3 e-77$ & NP_001036826.I & $117 / 270(43 \%)$ & $3 e-51$ \\
\hline 16 & Contig [4699] & AAX62029.I & Ostrinia nubilalis & $195 / 261$ (74\%) & $1 \mathrm{e}-102$ & NP_001036826.I & $|44 / 25|(57 \%)$ & $9 e-68$ \\
\hline 17 & ECB-23_F02 & CAM84318.I & Manduca sexta & $88 / 209(42 \%)$ & $3 e-36$ & No match & -- & -- \\
\hline 18 & ECB-V-25_E02 & AAX6203I.I & Ostrinia nubilalis & $32 / 32(100 \%)$ & $2 e-11$ & NP_001040430.I & $99 / 203$ (48\%) & $6 e-42$ \\
\hline \multicolumn{9}{|c|}{ Aminopeptidases } \\
\hline I & Contig [0722] & AAP3795I.I & $\begin{array}{l}\text { Helicoverpa } \\
\text { armigera }\end{array}$ & 72/193 (37\%) & $9 e-29$ & BAA337I5.I & $60 / 160(37 \%)$ & $2 e-21$ \\
\hline 2 & Contig [1364] & ABL0I48I.I & Ostrinia nubilalis & $4|3 / 42|$ (98\%) & 0.0 & NP_001037013.I & $273 / 422(64 \%)$ & $2 e-154$ \\
\hline 3 & Contig [1716] & XP_560264.3 & Anopheles gambiae & I32/354 (37\%) & $3 e-59$ & No match & -- & -- \\
\hline 4 & Contig [1907] & ACB87202.I & Ostrinia furnacalis & $370 / 374$ (98\%) & 0.0 & BAA337/5.I & $240 / 368(65 \%)$ & $8 e-135$ \\
\hline 5 & Contig [4362] & AAQ57405.I & $\begin{array}{l}\text { Helicoverpa } \\
\text { armigera }\end{array}$ & $102 / 263$ (38\%) & $2 e-48$ & NP_0010370I3.I & $89 / 266$ (33\%) & le-42 \\
\hline 6 & Contig [4298] & ACB47287.I & Ostrinia furnacalis & $291 / 297$ (97\%) & $3 e-167$ & NP_00I036834.I & $213 / 297(71 \%)$ & $6 e-118$ \\
\hline 7 & Contig [4992] & AAP3795I.I & $\begin{array}{l}\text { Helicoverpa } \\
\text { armigera }\end{array}$ & $168 / 246(68 \%)$ & $7 e-99$ & BAA337I5.I & $85 / 238(35 \%)$ & $6 e-38$ \\
\hline 8 & Contig [4529] & ABV0I346.I & Ostrinia furnacalis & $342 / 356(96 \%)$ & 0.0 & NP_00II $04835 . I$ & $226 / 350(64 \%)$ & $4 \mathrm{e}-125$ \\
\hline 9 & ECB-G02 & AAK85539.I & $\begin{array}{l}\text { Helicoverpa } \\
\text { armigera }\end{array}$ & $196 / 262(74 \%)$ & $2 \mathrm{e}-114$ & No match & -- & -- \\
\hline
\end{tabular}


Table 3: List of genes potentially involved in Bt toxicity and resistance as identified by EST analysis from the guts of the European corn borer larvae (Continued)

\begin{tabular}{|c|c|c|c|c|c|c|c|c|}
\hline 10 & ECB-D07 & ABQ5I393.I & Ostrinia furnacalis & $17 \mid / 22(75 \%)$ & le-99 & NP_00II 104835.1 & I59/225 (70\%) & $2 e-95$ \\
\hline II & ECB-DI2 & ABV0I346.I & Ostrinia furnacalis & $200 / 278(71 \%)$ & $|e-1| 2$ & NP_00I I 04835.1 & I55/275 (56\%) & $5 e-80$ \\
\hline 12 & ECB-C06 & ABL0I48I.I & Ostrinia nubilalis & $40 / 40(100 \%)$ & $9 e-16$ & NP_001037013.1 & $23 / 39(58 \%)$ & $7 e-07$ \\
\hline 13 & ECB-F04 & AAP3795I.I & $\begin{array}{l}\text { Helicoverpa } \\
\text { armigera }\end{array}$ & $117 / 208(56 \%)$ & $2 e-6 I$ & BAA32475.I & $67 / 190(35 \%)$ & $2 e-24$ \\
\hline \multicolumn{9}{|c|}{ Alkaline phosphatases } \\
\hline I & Contig [509I] & NP_001037536.2 & Bombyx mori & $101 / 172(58 \%)$ & $3 e-53$ & NP_00I037536.2 & $101 / 172(58 \%)$ & $3 e-53$ \\
\hline 2 & Contig [2328] & BAF62I 24.1 & Bombyx mandarina & $176 / 260(67 \%)$ & $8 e-103$ & NP_00I037536.2 & $177 / 260(68 \%)$ & $2 e-102$ \\
\hline \multicolumn{9}{|c|}{$\begin{array}{l}\text { Cadherin-like } \\
\text { protein }\end{array}$} \\
\hline i & ECB-B09 & ABS59299.1 & Ostrinia furnacalis & $242 / 244$ (99\%) & $7 e-135$ & BAA99405.I & I55/247 (62\%) & $|e-8|$ \\
\hline
\end{tabular}

a Sequence with highest score in BLASTX search

$b$ Match of ECB ESTs with silkworm sequence using BLASTX

\section{Conclusion}

Our study resulted in a gut-specific EST database containing 12,519 high-quality ESTs from a total of 15,000 ESTs sequenced in an agriculturally important lepidopteran pest. To our knowledge, this database represents the largest gut-specific EST database from a lepidopteran pest. Our analysis using ORF predictor software showed that approximately $11.2 \%$ of the protein coding genes in our database may be specific to ECB as these sequences have an ORF of at least 450 bp but did not have significant matches with known sequences in NCBI database. We have also identified 52 candidate genes that are relevant to Bt toxicity and resistance. These genes encode trypsin-like proteases, chymotrypsin-like proteases, aminopeptidases, cadherin-like protein, and alkaline phosphatases. Furthermore, we showed differential expressions of 15 out of the 41 representative candidate genes that were examined by RT-PCR, including 5 genes with apparently decreased expressions and 10 with increased expressions in Cry1Abresistant strain. These results may help us further narrow down the candidate genes possibly involved in Cry $1 \mathrm{Ab}$ resistance, and provide us with new insights into the mechanism of Bt resistance in general in ECB.

We are in the process of developing a microarray using our unique ESTs together with the ECB gut-specific sequences which are already available in the GenBank. The microarray technology will help us analyze the global change of gene expression in response to Bt protoxins/toxins. It will also allow us to analyze any genetic differences between $\mathrm{Bt}$ resistant and -susceptible strains of ECB. Our genomic information on ECB could also serve as a valuable resource for identifying critical/vulnerable genes from the gut of ECB that would make useful physiological targets for new toxins that could be developed for use in pest management.

\section{Methods}

\section{Insects rearing and dissection}

The KS-SC Bt-susceptible ECB colony was used for generating EST libraries. This colony originated from the egg masses collected from the cornfields near St. John, Kansas, in 1995. The colony has been reared since then on artificial diets in the laboratory at Kansas State University according to Huang et al. [63]. The resistant ECB strain originated from a field collection of 126 diapausing larvae obtained from non-Bt hybrids in Kandiyohi Co., MN in 2001. The resistant strain was initiated from 14 larvae that survived exposure to a diagnostic Cry1Ab concentration used to identify potential changes in susceptibility to Cry1Ab [64,65]. To minimize inbreeding or founder effects, the resistant insects were backcrossed twice with the susceptible strain which originated from the same collection. Because the resistance was incompletely recessive and involved multiple factors [65], the $\mathrm{F}_{1}$ progeny were randomly mated to obtain recombination of resistance factors in the $\mathrm{F}_{2}$ progeny to allow selection of resistant genotypes. The insects were then subjected to selection at a Cry $1 \mathrm{Ab}$ concentration corresponding to two- to threefold the $\mathrm{LC}_{50}$ for the $\mathrm{F}_{1}$ progeny $\left(150 \mathrm{ng} / \mathrm{cm}^{2}\right)$ [66]. This selection event was designed to eliminate all the susceptible homozygotes and most of the heterozygotes. The resistant survivors from this selection event were then subjected to a second cycle of backcrossing, random mating, and selection. After six generations, the Cry1Ab concentration used in selections was gradually increased to achieve $750 \mathrm{ng} / \mathrm{cm}^{2}$ at generation $\mathrm{F}_{10}$, a concentration that kills virtually all $\mathrm{F}_{1}$ progeny. At generation $\mathrm{F}_{17}$, the resistance to Cry $1 \mathrm{Ab}$ in the re-selected strain was in excess of 800 -fold. The guts were dissected from fifth-instar larvae in DEPC (diethylpyrocarbonate)-treated distilled water and were stored in TRI reagent ${ }^{\mathrm{TM}}$ (Molecular Research, Inc., Cincinnati, $\mathrm{OH})$ at $-80^{\circ} \mathrm{C}$ until used.

\section{cDNA library construction and sequencing}

Total RNA was isolated from the whole guts of ECB larvae using TRI reagent ${ }^{\mathrm{TM}}$. The plasmid library was constructed using Creator SMART ${ }^{\mathrm{TM}}$ cDNA library construction kit from Clontech (Palo Alto, CA) following the manufacturer's protocols with one modification; instead of using the original phage vector, PCR fragments were cloned directly into a pPCR-XL-TOPO plasmid using a TOPO TA 


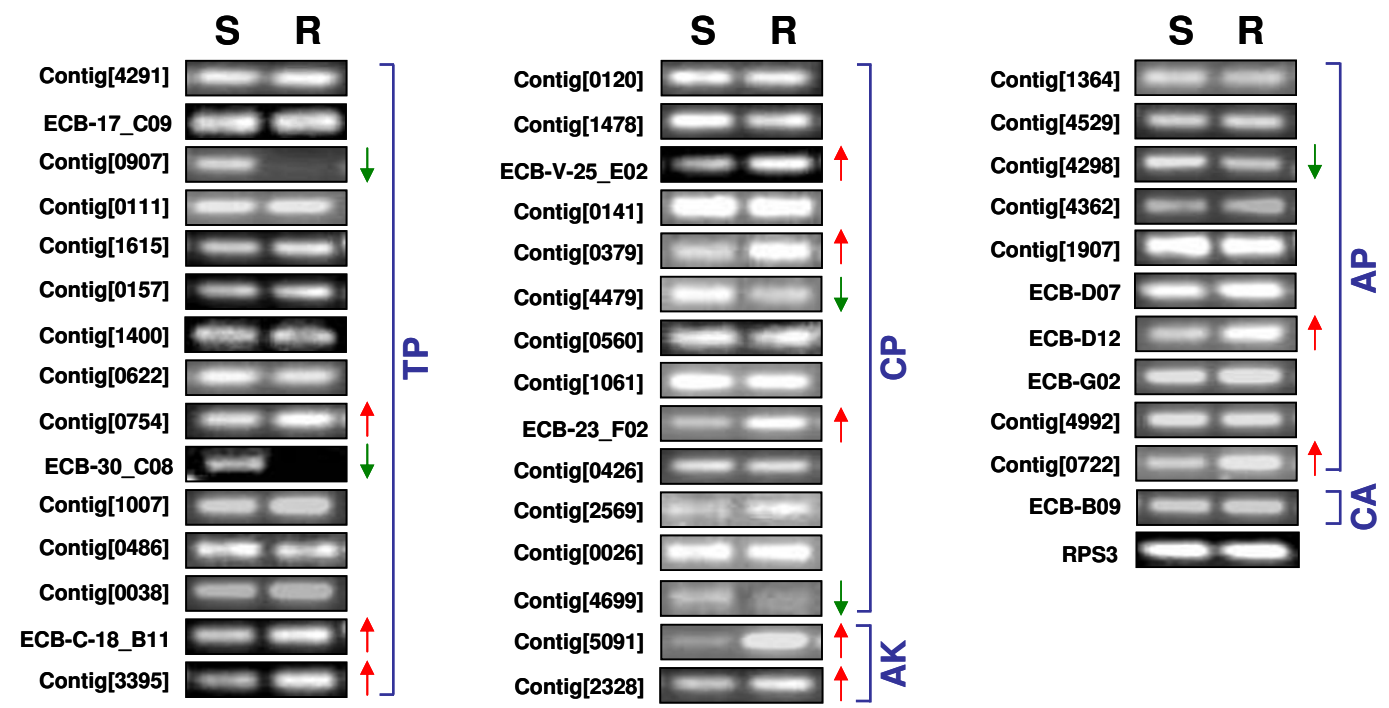

\section{Figure 6}

Expression profiles of $4 \mathrm{I}$ candidate genes relevant to $\mathrm{Bt}$ toxicity and resistance, which include 15 trypsin-like serine protease (TP), I 3 chymotrypsin-like serine protease (CP), 2 alkaline phosphatase (AK), 10 aminopeptidase (AP), and I cadherin-like protein (CA) genes in the midgut of one-day-old fifth-instar larvae in Cry IAbsusceptible (S) and resistant (R) strains of ECB as determined by RT-PCR. The arrows next to the gel pictures indicate the apparently decreased $(\downarrow)$ or increased $(\uparrow)$ expression of a particular gene in Cryl Ab-resistant strain as compared with the susceptible strain of ECB. The ribosomal S3 (RPS3) gene was used as a reference gene. At least two biological replications were used for each primer pair. The sequences of PCR primers used in this study were given in Appendix A.

cloning kit (Invitrogen, Carlsbad, CA). The $\lambda$-library was constructed using ZAP-cDNA synthesis kit and ZAP-cDNA Gigapack III gold cloning kit (Stratagene, La Jolla, CA) according to the manufacturer's protocols. Briefly, double stranded cDNA was synthesized from poly(A) RNA, sizefractionated through a Sepharose CL-2B gel filtration column, and ligated into $\lambda$ Uni-ZAP XR vector. The ligated DNA was packaged with the Gigapack III gold packaging extract and the library was plated on LB/agar plates. Recombinant plasmid within the lambda Uni-ZAP XR vector was in vivo excised using the ExAssist helper phage and recircularized to generate subclones in the pBluescript SK phagemid vector. To sequence the clones, M13R and M13F primers were used for 5' and 3' sequencing, respectively. Plasmid DNA was isolated using Qiagen Bio Robot 3000 and sequenced using an ABI 3700 DNA analyzer.

\section{EST analyses and annotations}

The DNA sequences were preprocessed by using the online software EGassembler [38]. Specifically, sequence cleaning process was employed to trim the vector and adaptor sequences from the ESTs. RepeatMasker process was used to mask the interspersed repeats and low complexity regions of the sequences by using Drosophila Repbase repeat library. The sequences were further masked by using vector masking against NCBI's vector library and organelle masking against mitochondrial library. The pre- processed ESTs were then assembled by using Sequencher software (Gene Codes Corp., Ann Arbor, MI). The ORF regions of the assembled ESTs were identified by using the ORF predictor software [67] and secretory proteins were identified by looking for signal peptide sequence using SignalP software [43]. Gene ontology (GO) annotation was derived using Blast2GO software http:// www.blast2go.de/[68].

\section{Comparative analysis of ESTs}

The ECB unique ESTs were comparatively analyzed for their sequence similarities against other organisms. The organism associated with the EST showing the highest BLAST score in GenBank databases was selected. The ECB gut ESTs were also compared with sequences from the silkworm and ECB that are currently available in the database by using BLASTN with a cutoff $E$-value of $10^{-3}$.

\section{Expression profiling by RT-PCR}

Forty-one out of the 52 candidate genes were selected for comparing their apparent gene expression profiles between the Cry1Ab-susceptible and resistant strains of ECB by using RT-PCR. These genes were selected solely based on their representations among different gene groups from our EST analysis. After total RNA was isolated from four midguts dissected from one-day-old fifth-instar larvae of each strain (Cry1Ab-susceptible and resistant 
strains) of ECB by using TRI reagentTM (Sigma, St. Louis, $\mathrm{MO}$ ), it was treated with TURBO ${ }^{\mathrm{TM}}$ DNase (Ambion, Austin, TX)to remove any genomic DNA contaminations. Three micrograms of total RNA was used for synthesis of first strand cDNA using SuperScript ${ }^{\circledast}$ III First-Strand Synthesis System (Invitrogen, Carlsbad, CA). cDNA prepared from total RNA was used as a template for RT-PCR. A minimum of two biological replications was used for all the PCR primer pairs. For all trypsin-like (except for ECB30_C08) and chymotrypsin-like serine protease, alkaline phosphatase, and RPS3 genes, 25 PCR cycles were used whereas for aminopeptidase and cadherin-like protein, 27 PCR cycles were used. For one trypsin-like serine protease gene (ECB-30_C08), however, 33 PCR cycles were used as the expression of this gene using fewer cycles was not visible on agarose gels. Each PCR was performed for above mentioned number of cycles, each consisting of $94^{\circ} \mathrm{C}$ for $30 \mathrm{~s}, 55^{\circ} \mathrm{C}$ for $60 \mathrm{~s}$, and $72^{\circ} \mathrm{C}$ for $60 \mathrm{~s}$. The sequences of forward and reverse PCR primers, and expected size of PCR product for each of 41 candidate genes are provided in Additional file 1.

\section{Authors' contributions}

$\mathrm{CK}$ conducted the major part of this study including experimental design, construction of the cDNA libraries, EST analysis, RT-PCR analysis, and manuscript preparation. YCZ participated in experimental design, EST sequencing and preliminary analysis of EST data. MSC assisted in the development of the project, the establishment of the collaboration in EST sequencing, and manuscript preparation. LLB participated in experimental design, maintenance of the insect culture, and manuscript preparation. RAH participated in the development of the project and experimental design. JY assisted in EST sequencing and analysis. BDS and ALBC contributed materials and participated in data analysis and manuscript preparation. SM participated in experimental design and manuscript preparation. KYZ coordinated the project and participated in experimental design, EST analysis, and manuscript preparation. All authors read and approved the final manuscript.

\section{Additional material}

\section{Additional file 1}

Sequences of PCR primers used to compare the gene expression profiles of trypsin-like and chymotrypsin-like serine proteases, alkaline phosphatases, aminopeptidases, and cadherin-like protein by RT-PCR between Cry1Ab-susceptible and resistant strains of European corn borer (Ostrinia nubilalis). The information provided represents the sequences of forward and reverse PCR primers, and expected size of PCR product for each of 41 candidate genes.

Click here for file

[http://www.biomedcentral.com/content/supplementary/1471-

2164-10-286-S1.doc]

\section{Acknowledgements}

The authors thank Yoonseong Park for his helpful comments on an earlier draft of this manuscript, Lisa Tan for maintaining the European corn borer colonies, Xiang Liu for his technical assistance. Mention of trade names or commercial products in this publication is solely for the purpose of providing specific information and does not imply recommendation or endorsement by U.S. Department of Agriculture or Kansas State University. This study was supported in part by the Kansas Agricultural Experiment Station and the Arthropod Genomics Center funded by K-State Targeted Excellence program at Kansas State University. This paper is contribution No 09105-J from the Kansas Agricultural Experiment Station. The Ostrinia nubilalis voucher specimens (voucher No. 079) are located in the Kansas State University Museum of Entomological and Prairie Arthropod Research, Manhattan, Kansas.

\section{References}

I. Adams MD, Celniker SE, Holt RA, Evans CA, Gocayne JD, Amanatides PG, Scherer SE, Li PW, Hoskins RA, Galle RF, et al.: The genome sequence of Drosophila melanogaster. Science 2000, 287:2185-2195

2. Holt RA, Subramanian GM, Halpern A, Sutton GG, Charlab R, Nusskern DR, Wincker P, Clark AG, Ribeiro JM, Wides R, et al.: The genome sequence of the malaria mosquito Anopheles gambiae. Science 2002, 298(559 I): 129-149.

3. Nene V, Wortman JR, Lawson D, Haas B, Kodira C, Tu ZJ, Loftus B, Xi Z, Megy K, Grabherr M, et al.: Genome sequence of Aedes aegypti, a major arbovirus vector. Science 2007, 316:1718-1723.

4. The Honeybee Genome Sequencing Consortium: Insights into social insects from the genome of the honeybee Apis mellifera. Nature 2006, 443:931-949.

5. Mita K, Kasahara M, Sasaki S, Nagayasu Y, Yamada T, Kanamori H, Namiki N, Kitagawa M, Yamashita H, Yasukochi $Y$, et al.: The genome sequence of silkworm, Bombyx mori. DNA Res 2004, il:27-35.

6. Xia Q, Zhou Z, Lu C, Cheng D, Dai F, Li B, Zhao P, Zha X, Cheng T, Chai $C$, et al.: A draft sequence for the genome of the domesticated silkworm (Bombyx mori). Science 2004, 306: 1937- 1940.

7. Tribolium Genome Sequencing Consortium: The genome of the model beetle and pest Tribolium castaneum. Nature 2008, 452:949-955.

8. Crosby MA, Goodman JL, Strelets VB, Zhang P, Gelbart WM, the FlyBase Consortium: FlyBase: genomes by the dozen. Nucleic Acids Res 2007, 35:D486-D49I.

9. Lin MF, Carlson JW, Crosby MA, Matthews BB, Yu C, Park S, Wan $\mathrm{KH}$, Schroeder AJ, Gramates LS, St Pierre SE, et al:: Revisiting the protein-coding gene catalog of Drosophila melanogaster using I 2 fly genomes. Genome Res 2007, I7:1823-1836.

10. Deng Y, Dong Y, Thodima V, Clem RJ, Passarelli AL: Analysis and functional annotation of expressed sequence tags from the fall armyworm Spodoptera frugiperda. BMC Genomics 2006, 7:264.

II. Grimmelikhuijzen C], Cazzamali G, Williamson M, Hauser F: The promise of insect genomics. Pest Manag Sci 2007, 63:4I3-416.

12. Sattelle DB, Jones AK, Buckingham SD: Insect genomes: challenges and opportunities for neuroscience. Invert Neurosci 2007, 7:133-136.

13. Pierce NE: Predatory and parasitic Lepidoptera: carnivores living on plants. J Lepido Soc 1995, 49:412-453.

14. Gerhold D, Caskey CT: It's the genes! EST access to human genome content. BioEssays 1996, 18:973-98I.

15. Dimopoulos G, Casavant TL, Chang S, Scheetz T, Roberts C, Donohue M, Schultz J, Benes V, Bork P, Ansorge W: Anopheles gambiae pilot gene discovery project: Identification of mosquito innate immunity genes from expressed sequence tags generated from immune-competent cell lines. Proc Natl Acad Sci 2000, 97:6619-6624.

16. Porcel BM, Tran AN, Tammi M, Nyarady Z, Rydaker M, Urmenyi TP, Rondinelli E, Pettersson U, Andersson B, Aslund L: Gene survey of the pathogenic protozoan Trypanosoma cruzi. Genome Res 2000, 10:1103-1107.

17. Mita K, Morimyo M, Okano K, Koike $\mathrm{Y}$, Nohata J, Kawasaki H, Kadono-Okuda K, Yamamoto K, Suzuki MG, Shimada T, Goldsmith 
MR, Maeda S: The construction of an EST database for Bombyx mori and its application. Proc Natl Acad Soc USA 2003, I00:|4|2|-|4|26.

18. Li L, Krell PJ, Arif BM, Feng Q, Doucet D: Integration and Analysis of an EST database from the insect Choristoneura fumiferana. 2003 [http://www.pestgenomics.org/database.htm]

19. Dong D-J, He H-J, Chai LQ, Jiang XJ, Wang JX, Zhao XF: Identification of genes differentially expressed during larval molting and metamorphosis of Helicoverpa armigera. BMC Dev Biol 2007, 7:73

20. Eum J, Kang S, Han S: Annotated expressed sequence tags for studies on the expression pattern of the immunized Plutella xylostella. [http://www.uniprot.org/uniprot/Q60FS0]

21. Robertson H, Martos MR, Sears CR, Todres EZ, Walden KKO, Nard JB: Diversity of odourant binding proteins revealed by an expressed sequence tag project on male Manduca sexta moth antennae. Insect $\mathrm{Mol} \mathrm{Biol}$ 1999, 8:50 I-5 I8.

22. Zou Z, Najar F, Wang Y, Roe B, Jiang H: Pyrosequence analysis of expressed sequence tags for Manduca sexta hemolymph proteins involved in immune responses. Insect Biochem Molec Bio 2008, 38:677-682

23. Nègre V, Hôtelier T, Volkoff AN, Gimenez S, Cousserans F, Mita K, Sabau X, Rocher J, Lopez-Ferber M, D'Alençon E, Audant P, Sabourault C, Bidegainberry V, Hilliou F, Fournier P: SPODOBASE: an EST database for the lepidopteran crop pest Spodoptera. BMC Bioinformatics 2006, 7:322.

24. Simpson R, Newcomb RD, Gatehouse HS, Crowhurst RN, Chagné D, Gatehouse LN, Markwick NP, Beuning LL, Murray C, Marshall SD, et al: Expressed sequence tags from the midgut of Epiphyas postvittana (Walker). (Lepidoptera: Tortricidae). Insect Mol Biol 2007, I 6:675-690.

25. Hegedus D, Baldwin D, O'Grady M, Braun L, Gleddie S, Sharpe A Lydiate D, Erlandson M: Midgut proteases from Mamestra configurata (Lepidoptera: Noctuidae) larvae: characterization, cDNA cloning, and expressed sequence tag analysis. Arch Insect Biochem Physiol 2003, 53:30-47.

26. Coates BS, Sumerford DV, Hellmich RL, Lewis LC: Mining an Ostrinia nubilalis midgut expressed sequence tag (EST) library for candidate genes and single nucleotide polymorphisms (SNPs). Insect Molec Biol 2008, I 7:607-620.

27. Ostlie KR, Hutchison WD, Hellmich RL: Bt corn and European corn borer: long-term success through resistance management. NCR Publication 602. University of Minnesota, St. Paul, MN 1997.

28. Gould F: Sustainability of transgenic insecticidal cultivars: integrating pest genetics and ecology. Annu Rev Entomol 1998, 43:701-726.

29. Wolfenbarger LL, Phifer PR: Biotechnology and ecology - The ecological risks and benefits of genetically engineered plants. Science 2000, 290:208-2093.

30. Huang F, Higgins RA, Buschman LL: Baseline susceptibility and changes in susceptibility to Bacillus thuringiensis subsp. kurs taki under selection pressure in European corn borer (Lepidoptera: Pyralidae). J Econ Entomol 1997, 90: I I 37-43.

31. Bolin PC, Hutchison WD, Andow DA: Long-term selection for resistance to Bacillus thuringiensis CrylAc endotoxin in a Minnesota population of European corn borer (Lepidoptera: Crambidae). J Econ Entomol 1999, 92:1021-1030.

32. Gill SS, Cowles EA, Pietrantonio PV: The mode of action of Bacillus thuringiensis $\delta$-endotoxin. Annu Rev Entomol 1992, 37:615-636.

33. Oppert B, Kramer KJ, Beeman RW, Johnson DE, McGaughey WH: Proteinase-mediated insect resistance to Bacillus thuringiensis toxins. I Biol Chem 1997, 272:23473-23476.

34. Huang F, Zhu KY, Buschman LL, Higgins RA, Oppert B: Comparison of midgut proteinases in Bacillus thuringiensis susceptible and -resistant European corn borer, Ostrinia nubilalis (Lepidoptera: Pyralidae). Pestic Biochem Physiol 1999, 65:I32-I39.

35. Li H, Oppert B, Higgins RA, Huang F, Zhu KY, Buschman LL: Comparative analysis of proteinase activities of Bacillus thuringiensis-resistant and -susceptible Ostrinia nubilalis (Lepidoptera: Crambidae). Insect Biochem Mol Biol 2004, 34:753-762.

36. Lee MK, Rajamohan F, Gould F, Dean DH: Resistance to Bacillus thuringiensis CrylA 士-endotoxins in a laboratory-selected
Heliothis virescens strain is related to receptor alteration. Appl Environ Microbiol 1995, 6 I:3836-42.

37. Herrero S, Oppert B, Ferre J: Different mechanisms of resistance to Bacillus thuringiensis toxins in the Indianmeal moth. Appl Environ Microbiol 2001, 67:1085-89.

38. Masoudi-Nejad A, Tonomura K, Kawashima S, Moriya Y, Suzuki M, Itoh M, Kanehisa M, Endo T, Goto S: EGassembler: online bioinformatics service for large-scale processing, clustering and assembling ESTs and genomic DNA fragments. Nucleic Acids Res 2006, 34:W459-462.

39. Papanicolaou A, Joron M, McMillan WO, Blaxter ML, Jiggins CD: Genomic tools and cDNA derived markers for butterflies. Mol Ecol 2005, I 4:2883-2897.

40. Li H, Oppert B, Higgins RA, Huang F, Buschman LL, Gao JR, Zhu KY: Characterizations of cDNAs encoding three trypsin-like proteinases and mRNA quantitative analyses in Bt-resistant and -susceptible Ostrinia nubilalis (Lepidoptera: Crambidae). Insect Biochem Mol Biol 2005, 35:845-860.

4I. Kikuchi T, Aikawa T, Kosaka H, Pritchard L, Ogura N, Jones JT: Expressed sequence tag (EST) analysis of the pine wood nematode Bursaphelenchus xylophilus and B. mucronatus. Mol Biochem Parasitol 2007, I 55:9-17.

42. Whitfield CW, Band MR, Bonaldo MF, Kumar CG, Liu L, Pardinas JR, Robertson HM, Soares MB, Robinson GE: Annotated expressed sequence tags and cDNA microarrays for studies of brain and behavior in the honey bee. Genome Res 2002, I 2:555-566.

43. Bendtsen JD, Nielsen H, von Heijne G, Brunak S: Improved prediction of signal peptides: SignalP 3.0. J Mol Biol 2004, 340:783-795.

44. O'Donnell RA, Blackman MJ: The role of malaria merozoite proteases in red blood cell invasion. Curr Opinion Microbiol 2005 , 8:422-427.

45. Adams MD, Soares MB, Kerlavage AR, Fields C, Venter JC: Rapid cDNA sequencing (expressed sequence tags) from a directionally cloned human infant brain cDNA library. Nat Genet 1993, 4:373-380.

46. Tosini F, Trasarti E, Pozio E: Apicomplexa genes involved in the host cell invasion: the Cpal35 protein family. Parassitologia 2006, 48: $105-107$

47. Ashburner M, Ball CA, Blake JA, Botstein D, Butler H, Cherry JM, Davis AP, Dolinski K, Dwight SS, Eppig JT, et al.: Gene ontology: tool for the unification of biology. The Gene Ontology Consortium. Nat Genet 2000, 25:25-29.

48. Bravo A, Gill SS, Soberón M: Mode of action of Bacillus thuringiensis Cry and Cyt toxins and their potential for insect control.

49. Ferré J, Van RJ: Biochemistry and genetics of insect resistance to Bacillus thuringiensis. Annu Rev Entomol 2002, 47:501-533.

50. Milne $\mathrm{R}$, Kaplan $\mathrm{H}$ : Purification and characterization of a trypsin-like digestive enzyme from spruce budworm (Choristoneura fumiferana) responsible for the activation of d-endotoxin from Bacillus thuringiensis. Insect Biochem Mol Biol 1993, 23:663-673.

5I. Oppert B, Kramer KJ, Johnson DE, Maclntosh SC, McGaughey WH: Altered protoxin activation by midgut enzymes from a Bacillus thuringiensis resistant strain of Plodia interpunctella. Biochem Biophys Res Commun 1994, I 98:940-947.

52. Oppert B, Kramer KJ, Johnson DE, Upton SJ, McGaughey WH: Luminal proteinases from Plodia interpunctella and the hydrolysis of Bacillus thuringiensis Cry IAc protoxin. Insect Biochem Mol Biol 1996, 26:57I-583.

53. Martínez-Ramírez AC, Real MD: Proteolytic processing of Bacillus thuringiensis CryllIA toxin and specific binding to brush border membrane vesicles of Leptinotarsa decemlineata (Colorado potato beetle). Pestic Biochem Physiol 1996 , 54:II5-122.

54. Keller M, Sneh B, Strizhov N, Prudovsky E, Regev A, Koncz C, Schell J, Zilberstein A: Digestion of $\delta$-endotoxin by gut proteases may explain reduced sensitivity of advanced instar larvae of Spodoptera littoralis to CrylC. Insect Biochem Mol Biol 1996, 26:365-373.

55. Forcada C, Alcacer E, Garcera MD, Martinez R: Differences in the midgut proteolytic activity of two Heliothis virescens strains, one susceptible and one resistant to Bacillus thuringiensis. Arch Insect Biochem Physiol 1996, 3 I:257-272.

56. Forcada C, Alcacer E, Garcera MD, Tato A, Martinez R: Resistance to Bacillus thuringiensis CrylAc toxin in three strains of 
Heliothis virescens: proteolytic and SEM study of the larval midgut. Arch Insect Biochem Physiol 1999, 42:5I-63.

57. Herrero S, Gechev T, Bakker PL, Moar WJ, Maagd RA: Bacillus thuringiensis CrylCa-resistant Spodoptera exigua lacks expression of one of four aminopeptidase $\mathbf{N}$ genes. BMC Genomics 2005, 6:96.

58. Hara H, Atsumi S, Yaoi K, Nakanishi K, Higurashi S, Miura N, Tabunoki $H$, Sato $R$ : A cadherin-like protein functions as a receptor for Bacillus thuringiensis Cry IAa and CrylAc toxins on midgut epithelial cells of Bombyx mori larvae. FEBS Lett 2003, 538:29-34.

59. Jurat-Fuentes JL, Adang MJ: Characterization of a CrylAcreceptor alkaline phosphatase in susceptible and resistant Heliothis virescens larvae. Eur J Biochem 2004, 27I:3|27-3I35.

60. Rajagopal R, Sivakumar S, Agrawal N, Malhotra P, Bhatnagar RK: Silencing of midgut aminopeptidase $\mathbf{N}$ of Spodoptera litura by double-stranded RNA establishes its role as Bacillus thuringiensis toxin receptor. J Biol Chem 2002, 277:46849-4685I.

6I. Gahan LI, Gould F, Heckel DG: Identification of a gene associated with Bt resistance in Heliothis virescens. Science 200I, 293:857-860.

62. Fernandez LE, Aimanova KG, Gill SS, Bravo A, Soberón M: A GPIanchored alkaline phosphatase is a functional midgut receptor of Cry I IAa toxin in Aedes aegypti larvae. Biochem J 2006, 394:77-84.

63. Huang F, Higgins RA, Buschman LL: Baseline susceptibility and changes in susceptibility to Bacillus thuringiensis subsp. kurstaki under selection pressure in European corn borer, Ostrinia nubilalis Hübner (Lepidoptera: Pyralidae). J Econ Entomol 1997, 90: I I37-II 43.

64. Siegfried BD, Spencer T, Crespo ALB, Storer NP, Head GP, Owens $E D$, Guyer $D$ : Ten years of monitoring for $B$ t resistance in the European corn borer: What we know, what we don't know and what we can do better. Amer Entomol 2007, 53:208-2I4.

65. Crespo ALB, Spencer T, Alves AP, Hellmich RL, Blankenship EE, Magalhaes LC, Siegfried BD: On-plant survival and inheritance of resistance to CrylAb toxin from Bacillus thuringiensis in a field-derived strain of European corn borer, Ostrinia nubilalis. Pest Manag Sci 2009 in press.

66. Marçon PCRG, Young LJ, Steffey KL, Siegfried BD: Baseline susceptibility of European corn borer (Lepidoptera: Crambidae) to Bacillus thuringiensis toxins. J Econ Entomo 1999, 92:279-285.

67. Min XJ, Butler G, Storms R, Tsang A: OrfPredictor: predicting protein-coding regions in EST-derived sequences. Nucleic Acids Res 2005, 33:W677-680.

68. Conesa A, Gotz S, Garcia-Gomez JM, Terol J, Talon M, Robles M: Blast2GO: a universal tool for annotation, visualization and analysis in functional genomics research. Bioinformatics 2005 , 21:3674-3676.
Publish with Biomed Central and every scientist can read your work free of charge

"BioMed Central will be the most significant development for disseminating the results of biomedical research in our lifetime. "

Sir Paul Nurse, Cancer Research UK

Your research papers will be:

- available free of charge to the entire biomedical community

- peer reviewed and published immediately upon acceptance

- cited in PubMed and archived on PubMed Central

- yours - you keep the copyright
BioMedcentral 